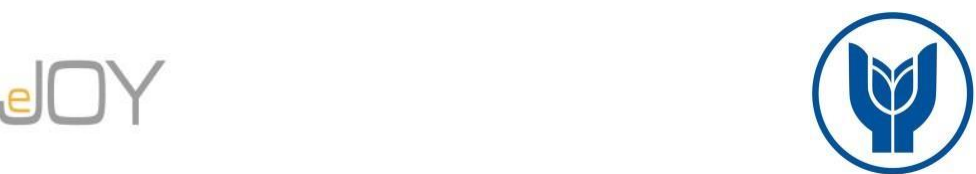

Müceldili, B., Tatar, B., Erdir, O. / Journal of Yasar University, 2021, 16/63, 1414-1429

\title{
Retaining the Best Talents: The Impact of Employer Branding and Psychological Capital
}

\section{En İyi Yetenekleri Elde Tutmak: İşveren Markasının ve Psikolojik Sermayenin Etkisi}

\author{
Büşra MÜCELDİLİ, Yı1dız Teknik Üniversitesi, Türkiye, busramu@yildiz.edu.tr \\ Orcid No: 0000-0003-2770-6137 \\ Berivan TATAR, Gebze Teknik Üniversitesi, Türkiye, btatar@gtu.edu.tr \\ Orcid No: 0000-0002-0934-3734 \\ Oya ERDİL, Gebze Teknik Üniversitesi, Türkiye, erdil@gtu.edu.tr \\ Orcid No: 0000-0003-3793-001X
}

\begin{abstract}
The concept of employer branding has attracted great attention of researchers in a variety of disciplines due to its role in attracting and retaining the best talents. However, few studies examine employer branding's impact on current employee behaviors. In this vein, the purpose of the study is to examine the antecedents and consequences of employer branding. The aforementioned hypotheses were tested via structural equation modeling and data obtained from 289 white-collar employees. Results empirically indicate that: (1) supportive organizational culture is positively associated with employer branding, (2) employer branding positively relates to intention to stay, (3) employer branding partially mediates the relationship between supportive organizational culture and intention to stay. Additionally, psychological capital moderates the relationship between employer branding and intention to stay.
\end{abstract}

Keywords: Supportive Organizational Culture, Psychological Capital, Employer Branding, Intention to Stay, Organizational Culture

\section{JEL Classification: M10, M12, M14}

$\ddot{O}_{z}$ İşveren markası kavramı, en iyi yetenekleri kuruma çekme ve elde tutmadaki rolü nedeniyle çeşitli disiplinlerdeki araştırmacıların büyük ilgisini çekmiştir. Ancak çok az çalışma, işveren markasının mevcut çalışan davranışları üzerindeki etkisini incelemiştir. Bu bağlamda çalışmanın amacı, işveren markasının öncül ve ardıllarını incelemektir. Araştırmaya konu olan hipotezler, yapısal eşitlik modellemesi ve 289 beyaz yakalı çalışandan elde edilen verilerle test edilmiştir. Sonuçlar şunu göstermektedir: (1) destekleyici örgüt kültürü, işveren markasıyla pozitif olarak ilişkilidir; (2) işveren markası, işte kalma niyetiyle pozitif olarak ilişkilidir; (3) işveren markası, destekleyici örgüt kültürü ve işte kalma niyeti arasındaki ilişkiye aracılık etmektedir. Ek olarak psikolojik sermaye, işveren markası ile işte kalma niyeti arasındaki ilişkide düzenleyici etkiye sahiptir.

Anahtar Sözcükler: Destekleyici Örgüt Kültürü, Psikolojik Sermaye, İsveren Markası, Işste Kalma Niyeti, Örgüt Kültürü

JEL Siniflandırmasi: M10, M12, M14

\section{Introduction}

Generally, individuals think brand when we talk about products, however, organizations also can be branded. Employer branding is an intersection concept of industrial and organizational psychology, organizational behavior, human resource management, and marketing. Thus, there are several studies about the conceptualization of employer branding in aspects of different fields. From a human resource perspective, Ambler and Barrow first suggested employer 
branding concept and classified total benefits as functional, economic and psychological. In this regard functional benefits refer to progression activities for career and personal development of subordinates; economic benefits indicate remuneration and monetary rewards; psychological benefits contribute to the well-being and belonging of employees through their recognition. Following Ambler and Barrow (1996), Berthon, Ewing and Hah (2005, 156) suggest employer attractiveness concept. They define employer attractiveness as the envisioned benefits that a potential employee sees in working for a specific organization. Moreover, they extended Ambler and Barrow's (1996) conceptualization through adding two more dimensions as application and interest value. This study also follows extended conceptualization with five dimensions.

In today's work environment employer brand is increasingly viewed as a human resource tool for organizational sustainability strategy (Aggerholm, Andersen, and Thomsen 2011), competitive advantage (Berthon et al. 2005) and superior performance (Wahba and Elmanadily 2015). Specifically, in the war for talent era, for retaining employees, organizations need to present some way of deeper purpose or meaning of what they do. We consider employer branding to be the process of building meaningfulness at existing employees and providing them willingness to stay in their organizations. Employer brand provides to understand employees' needs and aspirations and meet their expectations. Recently, branding is seen as a vehicle of meaning and is important in the management process (Karreman and Rylander 2008). Hence managing employer brand has gained importance for understanding employees implicitly and inhibiting turnover in organizations. In the face of high-pressure workplace employer branding offers career opportunities, training and growth to the employees. Therefore, employer branding enhances meaningfulness at work and facilitates retention.

Nevertheless, whereas most studies have discussed or investigated the concept of employer branding at the potential employees (Mölk and Auer 2018), few studies demonstrate employer branding at the existing employees. Furthermore, although the term of employer branding is mentioned in the studies of current employees, the studies are nascent for an empirical test in white-collar employment.

It is important to note that there are inconsistencies among the target groups of employer branding. In the literature, it has been showed that employer branding has three trivets, namely are customer, potential employee, and current employee. For instance, considering the reflections of the employer brand on the customers, it is seen that the organizations having strong employer brand (Google, Facebook, Coke... etc.) attract more attention from the society. Powerful employer brand also spread among both potential and existing employees quickly. 
In addition to the lack of empirical studies of employer branding, the antecedents and consequences of employer branding have not been investigated in the literature thus far. Cascio and Graham (2016) indicated that there is a scarcity in empirical research which helps to advance the theoretical understanding of the interrelationships among constructs. In terms of consequences of employer branding, we investigated turnover intention and retention as recommended by Cascio and Graham (2016). Additionally, the moderating variables that shape the relation between employer branding and intention to stay have received less attention in the literature. Thus, we are interested in whether psychological capital moderates employer branding turnover intention relationship. Therefore, this study investigated (i) the role of supportive organizational culture on employer branding (ii) the effects of employer branding on the intention to stay and (iii) the moderating effect of PsyCap on the relationship among employer branding and intention to stay.

\section{Literature Review}

\subsection{Employer Branding}

The concept of employer branding which describes envisioned benefits that employers provide for employees working for a specific organization is classified by Berthon et al., (2005) as a social value, economic value, application value, interest value, and development value.

As social relations and interactions are an essential aspect of the work environment, social value through the good relationship with other employees and superiors, happy working environment and supportive colleagues form the perception of a great place to work. Additionally, good working atmosphere, mutual cooperation, and good communication among the members of the organization have been considered within the social value of the employer branding (De Vos, Buyens, and Schalk 2003).

Economic value is used for evaluating the extent to which employees attribute value to economic opportunities as salary, attractive compensation package and promotion opportunities (Charbonnier-Voirin, Poujol, and Vignolles 2017). In addition to this, Srivastava and Bhatnagar (2010) stated that the fairness and credibility of the organizations are also important in the appraisal process and distribution of these rewards. Absolute level of payment and the payment level compared to the employees working in similar positions and payment of other firms in the sector for the same position also influence the employer attractiveness from the points of existing employees (Ito, Brotheridge, and McFarland 2013).

Interest value corresponds to the attractiveness of employers in the way of providing an opportunity to use creativity skills and developing innovative products within the exciting 
working environment. Sivertzen, Nilsen and Olafsen (2013) have discussed the interest value in terms of innovation and stated that the existence of innovative practices and processes within the organization ensure the retention of the current employees in the organization.

Application value refers to assessing the extent to which employees have the opportunity to teach and apply what they have learned in the past. Being humanitarian and customer-oriented have been evaluated within the scope of application value (Berthon et al. 2005). Besides, the extent to which the work is meaningful and allows the employees to use their know-how and skills has been dealt within the application value (Dabirian, Kietzmann, and Diba 2017). In addition to being able to use the past information, Ahmad and Daud (2016) evaluated the possibility to share this information with others within the scope of application value and emphasized that this sharing could be done by coaching and mentoring.

Development value denotes the practices of employers based mainly on the career management and development of employees. With this regard, good training opportunities and ability to acquire competencies that may be useful in the future career, offered by employers are included within the scope of development value (O'Cass et al. 2011). Moreover, Srivastava and Bhatnagar (2010) noted that organizations contribute to the development of employees through career growth. Furthermore, career development opportunities provide good working experience among employees and generate the perception of great place to work (Wilden, Gudergan, and Lings 2010).

Based on the above definitions, we argue that employer brand attractiveness provides benefits to organizations. Employees make their job decisions based on evaluation of potential employers in terms of the opportunities and working conditions provided to current employees and, thus, employers organize and change themselves to attract and retain the best talents within the organization. Specifically, employer branding triggers positive outcomes among organizations' existing members. Indeed, with strong employer branding, organizational members create and affirm a sense of belonging (Edwards and Edwards 2013).

Having established the features of employer brand, we now develop the arguments regarding the role of supportive organizational culture as an antecedent of employer branding, how employer branding affects intention to stay and how psychological capital moderates the employer branding and intention to stay linkage. 


\section{Hypothesis Development}

\subsection{Supportive Organizational Culture and Employer Branding}

Organizational culture is an intriguing concept which is difficult to define such that as it is individual personality. O'Reily and Chatman $(1996,160)$ defined organizational culture as a "social control system that is based on shared norms and values that set expectations about appropriate attitudes and behavior for a member of the group". Strong and supportive organizational culture not only increases the financial performance and provides competitive advantage, but also plays an important role in attracting and retaining the employees (Zinko et al. 2017).

We argue that supportive organizational culture fosters the development of employer branding by building a cooperative place to work image among employees. A supportive organizational culture provides cooperation among employees and builds a strong organizational brand. Supportive organizational culture also affects the development of attractive employer brand by feeling encouraged, supported and valued. Research (Moroko and Uncles 2008) has shown that when the culture of an organization presents a supportive organizational culture and cares about employee benefits, employer brand is strengthened. Additionally, supportive organizational culture enhances employer branding by creating an atmosphere of committing to the personal and professional development of its employees. Organizational members having a sense of managerial supporting for their career they feel they have an attractive employer brand. On the basis of this background, we propose that:

H1. Supportive organizational culture is positively related to employer branding

\subsection{Employer Branding and Intention to Stay}

We argue that employer branding influences intention to stay by extra organizational ties. From this point of view, having a strong employer brand developed based on multidimensional benefits have contributed to gathering high employee retention (Kashyap and Rangnekar 2016; O'Cass et al. 2011). In this context, the unique values and benefits within the employer brand that employees gathered as a result of being a member of organizations lead them to remain in a current organization (Heger 2007; Edwards and Edwards 2013).

Furthermore, a positive employer brand image attracts employee's family and friends' perception of the firm (Tanwar and Prasad 2016). When the organization attracts employees' family and friends through their brand, employees are more motivated to be part of the organization. Employer brand is important for reinforcing the commitment of current employees to stay with that organization (Backhous and Tikoo 2004). We propose that: 
H2. Employer branding is positively related to the intention to stay.

\subsection{The Mediating Role of Employer Branding}

The importance of organizational culture for creating attractive employer brand has been recognized in the literature (Chhabra and Sharma 2014). With this regard, Ready, Hill and Jay (2016) pointed out that shared values such as a reward system based on merits, being aware of the importance of humans for organizational success, contributing employees ‘ achievements, the strong bond among all level of businesses have brought attractiveness and retention of subordinates for an extended period of time. Additionally, an organizational culture based on the empowerment of the employees, teamwork in the work practices, consistency between action and promises given by organizational values, continuous improvement and investment in skills of employees have attended employer brand attractiveness (Keino, Gachunga, and Ogollah 2017). Rampl (2014) also revealed that work content and culture, rather than the salary and advancement opportunities, are the important factors for being the employer of choice.

In this context, employees who feel themselves as a part of the organization with a strong employer brand are more willing to remain in existing workplaces as a result of this perception (Kashyap and Rangnekar 2016). For example, Tanwar and Prasad (2016) suggested that supportive work environment, work-life balance through flexible working, ability to work from home and training and development opportunities for the career and personal development make a contribution to employee retention. Conversely, unsupportive organizational culture (i.e. lack of job security, promotion opportunities, and flexibility in terms of duties and working hours) induce the intention to search a new job (Ito et al. 2013).

Based on these earlier findings, we propose that the existence of a supportive organizational culture leverages the perception of strong employer brand and this perception, as a result, will affect the intentions of employees to stay in their current organizations. Therefore,

H3. Supportive organizational culture positively relates to intention to stay.

H4. Employer branding mediates the relationship between supportive organizational culture and intention to stay.

\subsection{The Moderating Role of Psychological Capital}

Positive organizational behavior is mainly based on the strengths of human capital as well as psychological capabilities and being developable, changeable and manageable is one of the most important features of these capabilities (Luthans 2002). In this respect, employees having a higher level of psychological capital may tend to strengthen this psychological capacity in different ways. Especially, mastery experiences and social persuasion contributes to developing 
efficacy while participative initiatives and showing confidence improve the hope of employees. Additionally, employees develop their optimism through appreciation and flexible perspectives while they need the availability of necessary resources and secure work environment for enhancing their resiliency (Luthans and Youssef 2004).

In light of these arguments, we inferred that these components required for the development of psychological capital correspond to the aspects of the employer branding. With this regard, employees with high levels of psychological capital will tend to attribute importance to the employer branding, which may be an important instrument for developing their skills and psychological capabilities, and ultimately their intention to stay in the organization. At the same time, having a higher level of psychological capital might generate a favorable perception of employer branding.

From this perspective, high level of hope about their future, self-efficacy in achieving their job responsibilities, resilience in case of uncertainty and optimism about overcoming failure in work lead employees to stay in their current organization (Aveyet al. 2011) by virtue of getting the opportunities of enhancing their psychological capital through social, economic, development, application and interest value provided within the employer branding. As Moroko and Uncles (2008) indicated employer brand is strengthened when the firm corporate vision and personal benefits of employees are aligned.

In a nutshell, we posited that higher level of psychological capital strengthened the relationship between employer branding and intention to stay. Accordingly, we propose the following hypothesis:

H5. Psychological capital moderates the relationship between employer branding and intention to stay.

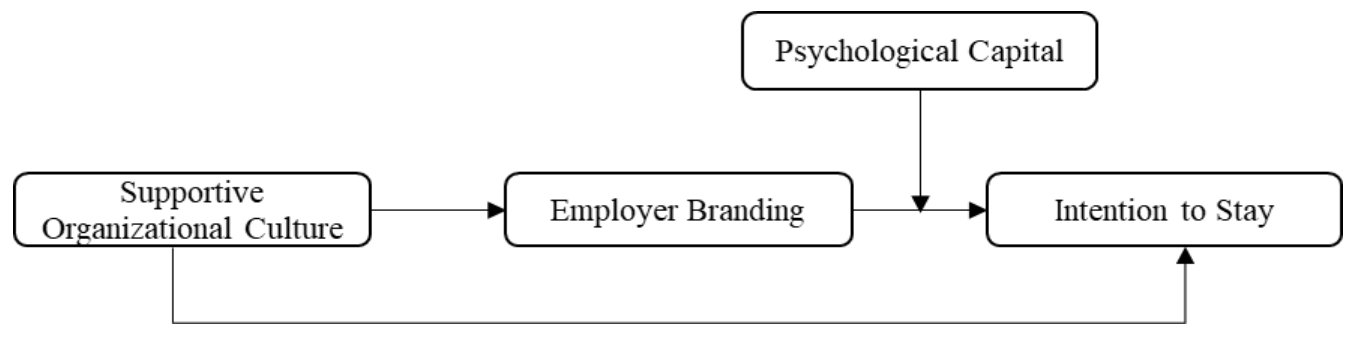

Figure 1. Research Model

\section{Data and Methodology}

\subsection{Measures}

To test the aforementioned hypotheses, multi-item scales were adopted from prior studies for the measurement of variables. We used 5 points Likert scale ranging from 1 (strongly disagree) to 5 (strongly agree). 
Supportive Organizational Culture. For the supportive organizational culture, we used 10 items from İpek (1999). A sample item is "Cooperation is preferred to competition".

Psychological Capital. For psychological capital, we used the scale PsyCap Scale from Luthans (2007). The scale included 24 items measuring the hope, optimism, self-efficacy and resiliency aspects of psychological capital. Sample items are "During a job search, things never work out the way I want them to" and "I feel confident analyzing a long-term problem to find a solution".

Employer Branding. For employer branding, we adopted 25 items scale of Berthon et al. (2005). The scale consisted of five subscales as economic value, development value, social value, interest value, and application value. Sample items are "Good promotion opportunities within the organization" and "Gaining career-enhancing experience".

Intention to Stay. For the intention to stay we modified Career Progression and Development scale which was developed by the State Services Commission (2013). A sample item includes "I am planning to work in this organization to the end of my career".

\subsection{Sampling}

Data were collected from 289 white-collar employees working in different occupational groups and sectors in Turkey. Because their native language is Turkish, we adopted parallel translation method for creating Turkish questionnaire. Items were translated both from English to Turkish and Turkish to English. Content validity was established by interviewing human resource scholars and industry experts. Both scholars and experts confirm that items were fully understandable.

In our sample, the respondents were $63.7 \%$ male and were $36.3 \%$ female. The average age was 31.4. The respondents of $34.4 \%$ held a high school degree, $47.2 \%$ of them had a bachelor degree, 16,4 of them had master's degree, and $2 \%$ had a doctorate degree. Average work experience of the participant was 2.5 years. The work experience of respondents was less than 1 year (13.9\%), 1-5 years $(40.5 \%), 6-10$ years $(20.5 \%)$ and more than 11 years $(25.1 \%)$.

\section{Findings}

\subsection{Measurement of Validity and Reliability}

After data collection, reliability and validity of measures were assessed through following Fornell and Larcker (1981). Firstly, we conducted a confirmatory factor analysis (CFA) for assessing unidimensionality (Anderson and Gerbing 1988).

After eliminating problematic items in a step by step procedure, CFA results indicated that the model fits the data adequately $(\chi 2=1072.961 ; \chi 2 / \mathrm{df}=1.86$; CFI $=.91 ; \mathrm{IFI}=.91$; $\mathrm{TLI}=.90$, 
PNFI = .75; RMSEA = .05). All items also loaded significantly on relevant constructs, providing support for convergent validity.

Table 1. Correlations and Descriptive Statistics

\begin{tabular}{lcccc}
\hline Variables & $\mathbf{1}$ & $\mathbf{2}$ & $\mathbf{3}$ & $\mathbf{4}$ \\
\hline Supportive Culture & $\mathbf{( . 7 3 )}$ & & & \\
Employer Branding & $.64^{* *}$ & $\mathbf{( . 7 4 )}$ & & \\
Psychological Capital & $.52^{* *}$ & $.65^{* *}$ & $\mathbf{( . 7 9 )}$ & \\
Intention to Stay & $.54^{* *}$ & $.57^{* *}$ & $.58^{* *}$ & $\mathbf{( . 8 1 )}$ \\
Mean & 3.91 & 3.97 & 3.98 & 3.77 \\
S. dev. & .72 & .60 & .60 & .90 \\
Composite reliability & .84 & .79 & .95 & .85 \\
Variance extracted & .51 & .55 & .62 & .65 \\
Cronbach's $\alpha$ & .82 & .91 & .89 & .84 \\
\hline ** $<.01 ;$ Values along the diagonal are the square root of AVE & & &
\end{tabular}

Table 1 shows the correlation among all variables. Moreover, the average variance extracted (AVE) for each variable and composite reliabilities are well beyond or close the threshold levels (Fornell and Locker 1981). Additionally, the squared root of AVE for each variable was greater than the estimated squared correlations of the factors as recommended by Fornell and Locker (1981).

\subsection{Hypothesis Testing}

To test the above hypotheses, we used SEM as our analysis methodology. Firstly, according to the results, obtained conceptual model adequately fits the data $(\chi 2=1081.588 ; \chi 2 / \mathrm{df}=1.96$; $\mathrm{CFI}=.90 ; \mathrm{IFI}=.89 ; \mathrm{TLI}=.90, \mathrm{PNFI}=.74 ; \mathrm{RMSEA}=.06)$.

Table 2. Model Results

\begin{tabular}{llccc}
\hline & Hypothesized path & $\begin{array}{c}\text { Path } \\
\text { Coefficient }\end{array}$ & t value & Results \\
\hline H1 & Supportive culture $\rightarrow$ Employer branding & $.69^{* *}$ & 7.610 & Supported \\
H2 & Employer branding $\rightarrow$ Intention to Stay & $.33^{*}$ & 2.384 & Supported \\
H3 & Supportive culture $\rightarrow$ Intention to Stay & $.37^{* *}$ & 2.898 & Supported \\
\hline${ }^{* p}<.05, * * p<.01$. & & &
\end{tabular}

The Table 2 indicates that supportive organizational culture is positively related to employer branding ( $\beta=.69, \mathrm{p}<.01$ ), supporting H1. Regarding H2, we found that employer branding is positively related to intention to stay $(\beta=.33, \mathrm{p}<.05)$. Additionally, we found a statistically significant relation between supportive organizational culture and intention to stay $(\beta=.37$, $\mathrm{p}<.01$ ), supporting $\mathrm{H} 3$. 
Table 3. Results of Mediating Analysis

\begin{tabular}{|c|c|c|c|}
\hline \multirow{2}{*}{ Direct and Indirect effects } & \multirow[b]{2}{*}{$\boldsymbol{\beta}$} & \multicolumn{2}{|c|}{$95 \% \mathrm{CI}$} \\
\hline & & LL CI & UL CI \\
\hline \multicolumn{4}{|l|}{ Direct effects } \\
\hline Supportive culture $\rightarrow$ Employer branding & $.54 * *$ & .46 & .61 \\
\hline Employer branding $\rightarrow$ Intention to Stay & $.48 * *$ & .35 & .61 \\
\hline Supportive culture $\rightarrow$ Intention to Stay & $.67 * *$ & .55 & .79 \\
\hline Indirect effect & & & \\
\hline $\begin{array}{l}\text { Supportive culture } \rightarrow \text { Employer branding } \rightarrow \text { Intention to } \\
\text { Stay }\end{array}$ & $.34 * *$ & .22 & .49 \\
\hline
\end{tabular}

Finally, for testing mediating and moderating hypotheses, the bootstrapping method (Preacher \& Hayes, 2008) was used. In this regard, mediation model was tested with Model 4 within the PROCESS macro for SPSS and 5000 bootstrap resamples were used with $95 \%$ confidence intervals.

Table 4. Results of Moderating Analysis

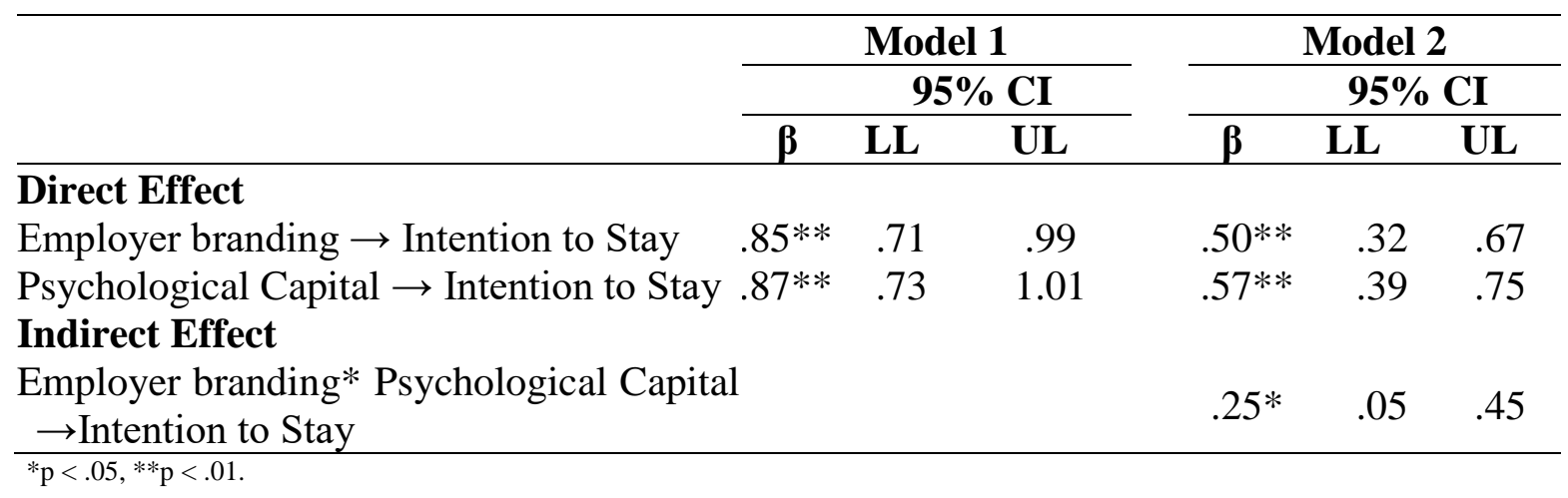

Table 3 indicates that supportive organizational culture positively relates to the employer branding ( $\beta=.54, p<.001 ; 95 \% \mathrm{CI}$ : .46-.61) and intention to stay $(\beta=.67, \mathrm{p}<.001 ; 95 \% \mathrm{CI}$ : $.55-.79)$. Besides, employer branding positively relates to intention to stay $(\beta=.48, p<.001$; 95\% CI: .35-.61). Employer branding also had mediation effects on the relationship between supportive organizational culture and intention to stay $(\beta=.34, \mathrm{p}<.001 ; 95 \% \mathrm{CI}$ : .22-.49), supporting H4.

To test the moderating effect of psychological capital on the relationship between employer branding and intention to stay, we used Model 1 within the PROCESS macro for SPSS and 5000 bootstrap resamples with 95\% confidence intervals (See Table 4). Regarding moderating analysis, we found that the interaction effect (employer branding*psychological capital) is significant $(\beta=.25, \mathrm{p}<.05 ; 95 \% \mathrm{CI}$ : .05-.45), supporting H5. We found that psychological capital moderates the relationship between employer branding and intention to stay. 
Table 5. Results of hypothesized research model

\begin{tabular}{llc}
\hline Hypotheses & Path & Result \\
\hline H1 & Supportive culture $\rightarrow$ Employer branding & Supported \\
H2 & Employer branding $\rightarrow$ Intention to Stay & Supported \\
H3 & Supportive culture $\rightarrow$ Intention to Stay & Supported \\
H4 & Supportive culture $\rightarrow$ Employer branding $\rightarrow$ Intention to Stay & Supported \\
H5 & Employer branding* Psychological Capital $\rightarrow$ Intention to Stay & Supported \\
\hline
\end{tabular}

\section{Conclusion}

In addition to the product and corporate brand, the employer brand of organizations has an important role in gaining competitive advantage. In today's business world, organizations try to think of ways to overcome challenges in attraction and retention of talented human capital particularly caused by talent shortages. Hence, as one of this attractive way, organizations aim to create a great place to work perception through employer branding.

In this context, this study contributes to specifically human resource field by extending current literature on employer branding perspective on the existing employee. For example, employer branding has been conceptualized and operationalized by use of potential employee perspective (Highhouse and Lievens 2003) in past studies. In this study, we demonstrated the role of employer branding on the current employees which can provide a competitive advantage for the firms. Examining the employer brand perceptions of current employees also facilitate understanding the employees' attitudes and behaviors. In addition, understanding the dynamics within the organization that affect the perception of employer brand enables to emergence of the desired employee behaviors.

This study also contributes to human resource management literature by showing the model of the interrelationship among supportive organizational culture, employer branding, stay intention and psychological capital. First, we empirically showed that, as a part of organizational culture, a supportive organizational culture that fosters cooperation provides an exciting and fun work environment and creates good relationship with employee's superiors and colleagues. Moreover, supportive organization culture provides to foster thinking creatively.

Second, the study showed that supportive organizational culture is positively related to intention to stay. This finding demonstrated that supportive organizational culture is one of the bases for retaining the employee in the firm. In particular, collectivistic national culture provides commitment to the organization and they need to stay in their organization (Wasti 2002) and Turkey's national culture is collectivistic rather than becoming individualistic (Hofstede 2001) considering relationships are as family relationships (clan) in Turkish firms. 
Hence, employees want to stay with their organizations, they are highly committed to their organizations if they perceive themselves as a part of the firm.

Third, the study demonstrated that employer branding is positively related to the intention to stay. This finding especially highlights that when employees have the opportunity to work in organizations having a strong employer branding, they tend to remain in their organizations. The results support the findings of the study of Heger (2007) and Edwards and Edwards (2013) which was demonstrated that unique values and benefits provided through employer branding activities lead employees to stay in their organizations.

Fourth, the paper demonstrated that employer branding mediates the link between supportive organizational culture and intention to stay. While previous studies investigated the mediating role of employer branding between transformational leadership and intention to leave (Sahu, Pathardikar, and Kumar 2018), we specifically investigated the link between organizational culture and intention to stay. Our findings suggest that employer branding attractiveness is actualized through supportive organizational action and practices to leverage the intention to stay in the current organizations.

Lastly, the study theoretically formulates and empirically examines the moderating effect of psychological capital in the relationship between employer branding and intention to stay. It seems that employee psychological resources contribute to stay with the organization. It makes the employer brand attractiveness more visible to a current employee in the firm.

\subsection{Managerial Implications}

Todays' businesses make an effort to overcome challenges in attraction and retention of talented human capital caused by talent shortages. In this competitive work environment, it is important to create and polish employer branding. A human resource consulting firm -PES Surveyconducted a research about employee experiences and new trends through 64 firms from various sectors including Toyota, Flypgs and IKEA in 2018. Accordingly, results showed that employer branding management is the most important topic and human resource practitioners give priority to the topic. Based on this research, the management should (i) establish a supportive organizational culture that encourages employees to think creatively and outside of the box (ii) make investment for creating and sustaining positive employer brand image via different tools for example social media tools or business magazines (iii) develop employees with high psychological capital, because they could achieve to stay in the organization and lead to retention. 
In addition, in highly competitive working environment, not only attraction but also retention of the best talents becomes difficult as a result of the high competition in the labor market. Increasing turnover rates and supply for talented workforce have brought on additional replacement and recruitment cost. Besides, inefficiency has occurred as a result of employing non-qualified workforce to the organizations (Arnold, 2005). In this respect, managers should use employer brand as an attraction and retention strategy to reduce high turnover rates. The findings of the present study also revealed that employer branding is an important factor determining employees' intention to stay at work. On the other hand, managers should pay attention to the value propositions and working environment offered within the framework of the employer brand. The values defined within the employer brand should also be supported by the organizational climate, synergy and culture within the organization.

\subsection{Limitations and Future Research}

In addition to the above contributions, we should also note that there are some methodological limitations in the study. Firstly, in our study, we used a questionnaire which included the dependent and independent variables that were answered by the same respondents. Secondly, the study was conducted in Turkish firms and employees from Turkey which is characterized by collectivistic culture. Therefore, the results cannot be generalizable to different cultural contexts specifically individualistic culture such as North America. Third, cross-sectional studies did not let us examine real causality between the different measures or changes in the variables over time. To illustrate, internal capabilities and competitive strategies and advantages can be expected to evolve over time. In this vein, future studies may use a longitudinal design.

Our study also selected sample and its size is another limitation. In this regard, future research can choose to focus on a large variety of sectors and organizations. Besides, current study investigated the employer brand perception of white-collar employees. Future research can be expanded by examining the employer brand perception of blue-collar employees or comparison of perceptions of blue-collar and white-collar employees.

Future studies should also investigate the relationship among HR practices such as recruitment, training, career and pay incentives and employer branding in current employees. In particular, current study focused on the supportive organizational culture as an antecedent of employer brand. Future research can examine the other types of organizational culture to determine whether different types of organizational culture have different effects on employees' perception of employer brand. In addition to organizational culture, examining the effects of different antecedents (i.e. leadership styles, organizational climate, high quality connections) 
will also contribute to the employer brand literature. Similarly, future studies may examine the effects of personal variables, as well as organizational variables, such as gender, personality and work values on employer brand perception.

On the other hand, current study also investigated intention to stay as a consequence of employer brand. Other potential consequences (i.e. psychological wellbeing, affective wellbeing, job meaningfulness) may need to be considered to broaden the understanding of the employer brand concept. Furthermore, future research could focus on alternative moderators (i.e. intrinsic motivation, calling, compassion) in the link between employer brand and employees' behavior. 


\section{REFERENCES}

Aggerholm, H. K., Andersen, S. E., and Thomsen, C. 2011. "Conceptualising employer branding in sustainable organisations." Corporate Communications, $16(2), \quad 123$. https://doi.org/10.1108/13563281111141642

Ahmad, N. A., and Daud, S. 2016. "Engaging People with Employer Branding." Procedia Economics and Finance, 35(October 2015), 690-698. https://doi.org/10.1016/S2212-5671(16)00086-1

Anderson, J. C., and Gerbing, D. W. 1988. "Structural Equation Modeling in Practice: A Review and Recommended Two-Step Approach." Psychological Bulletin. https://doi.org/10.1037/00332909.103.3.411

Arnold, E. 2005. "Managing human resources to improve employee retention". The Health Care Manager, 24(2), 132-140.

Avey, J. B., Reichard, R. J., Luthans, F., and Mhatre, K. H. 2011. "Meta-analysis of the impact of positive psychological capital on employee attitudes, behaviors, and performance." Human Resource Development Quarterly, 22(2), 127-152. https://doi.org/10.1002/hrdq.20070

Backhaus, K., and Tikoo, S. 2004. "Conceptualizing and researching employer branding." Career Development International, 9(5), 501-517. https://doi.org/10.1108/13620430410550754

Berthon, P., Ewing, M., and Hah, L. L. 2005. "Captivating company: dimensions of attractiveness in employer branding." International journal of advertising, $24 \quad$ (2), 151-172. https://doi.org/10.1080/02650487.2005.110072912

Cascio, W. F., and Graham, B. Z. 2016. "New Strategic Role for HR: Leading the Employer-Branding Process." Organization Management Journal, 13(4), 182-192. https://doi.org/10.1080/15416518.2016.1244640

Charbonnier-Voirin, A., Poujol, J. F., and Vignolles, A. 2017. "From value congruence to employer brand: Impact on organizational identification and word of mouth". Canadian Journal of Administrative Sciences, 34(4), 429-437. https://doi.org/10.1002/cjas.1379

Chhabra, N. L., and Sharma, S. 2014. "Employer branding: Strategy for improving employer attractiveness." International Journal of Organizational Analysis, 22(1), 48-60. https://doi.org/10.1108/IJOA-09-20110513

Dabirian, A., Kietzmann, J., and Diba, H. 2017. “A great place to work!? Understanding crowdsourced employer branding.” Business Horizons, 60(2), 197-205. https://doi.org/10.1016/j.bushor.2016.11.005

De Vos, A., Buyens, D., and Schalk, R. 2003. "Psychological contract development during organizational socialization: Adaptation to reality and the role of reciprocity." Journal of Organizational Behavior, 24, 537-559. https://doi.org/10.1002/job.205

Edwards, M. R., and Edwards, T. 2013. "Employee responses to changing aspects of the employer brand following a multinational acquisition: a longitudinal study." Human Resource Management, 52(1), $27-54$. https://doi.org/10.1002/hrm.21519

Fornell, C., and Larcker, D. F. 1981. "Evaluating structural model with unobserved variables and measurement errors." Journal of Marketing Research, 18(1), 39-50. https://doi.org/10.1177/002224378101800104

Heger, B. K. 2007. "Linking the Employment Value Proposition (EVP) to employee engagement and business outcomes: Preliminary findings from a linkage research pilot study.” Organization Development Journal, 25(2), 121-132.

Highhouse, S., and Lievens, F. 2003. "The relation of instrumental and symbolic attributes to a company's attractiveness as an employer." Personnel Psychology, 56, 75-102. https://doi.org/10.1111/j.17446570.2003.tb00144.x

Hofstede, G. H. 2001. “Culture’s Consequences, Second Edition: Comparing Values, Behaviors, Institutions and Organizations Across Nations.” In Edn, Sage Publications, Inc, Thousand Oaks.

Ito, J. K., Brotheridge, C. M., and McFarland, K. 2013. "Examining how preferences for employer branding attributes differ from entry to exit and how they relate to commitment, satisfaction, and retention." Career Development International, 18(7), 732-752. https://doi.org/10.1108/CDI-05-2013-0067

Kashyap, V., and Rangnekar, S. 2016. "The Mediating Role of Trust: Investigating the Relationships among Employer Brand Perception and Turnover Intentions." Global Business Review, 17, 64S-75S. https://doi.org/10.1177/0972150916631083

Keino, D.C., Gachunga, H., and Ogollah, K. 2017. "Effect of Human Resource Practices, Organizational Culture and Employer Branding on the Mobile Telecommunication Sector in Kenya." Human Resource and Leadership Journal, 2(1), 80-100.

Krreman, D., and Rylander, A. 2008. "Managing meaning through branding - The case of a consulting firm." Organization Studies, 29(1), 103-125. https://doi.org/10.1177/0170840607084573

Luthans, F., Avolio, B. J., Avey, J. B., and Norman, S. M. 2007. "Positive psychological capital: Measurement and relationship with performance and satisfaction." Personnel psychology, 60(3), 541-572. https://doi.org/10.1111/j.1744-6570.2007.00083.x 
Luthans, F. 2002. "The need for and meaning of positive organizational behavior." Journal of Organizational Behavior, 23(6), 695-706. https://doi.org/10.1002/job.165

Luthans, F., and Youssef, C. M. 2004. "Human, Social, and Now Positive Psychological Capital Management" Organizational Dynamics, 33(2), 143-160. https://doi.org/10.1016/j.orgdyn.2004.01.003

Mölk, A., and Auer, M. 2018. "Designing brands and managing organizational politics: A qualitative case study of employer brand creation." European Management Journal, 36(4), 485-496. https://doi.org/10.1016/j.emj.2017.07.005

Moroko, L., and Uncles, M. D. 2008. "Characteristics of successful employer brands.” Journal of Brand Management, 16(3), 160-175. https://doi.org/10.1057/bm.2008.4

O'Cass, A., Schlager, T., Bodderas, M., Maas, P., and Cachelin, J. L. 2011. "The influence of the employer brand on employee attitudes relevant for service branding: an empirical investigation." Journal of Services Marketing, 25(7), 497-508. https://doi.org/10.1108/08876041111173624

Preacher, K. J., and Hayes, A. F. 2008. "Asymptotic and resampling strategies for assessing and comparing indirect effects in multiple mediator models." Behavior Research Methods, 40(3), 879-891. https://doi.org/10.3758/BRM.40.3.879

Rampl, L. V. 2014. "How to become an employer of choice: transforming employer brand associations into employer first-choice brands." Journal of Marketing Management, 30(13-14), 1486-1504. https://doi.org/10.1080/0267257X.2014.934903

Ready, D. A., Hill, L. A., and Conger, J. A. 2008. "Winning the race for talent in emerging markets." Harvard business review, 86(11), 62-70.

Sahu, S., Pathardikar, A., and Kumar, A. 2018. "Transformational leadership and turnover: Mediating effects of employee engagement, employer branding, and psychological attachment." Leadership and Organization Development Journal, 39(1), 82-99. https://doi.org/10.1108/LODJ-12-2014-0243

Sivertzen, A. M., Nilsen, E. R., and Olafsen, A. H. 2013. "Employer branding: Employer attractiveness and the use of social media." Journal of Product and Brand Management, 22(7), 473-483. https://doi.org/10.1108/JPBM-09-2013-0393

Tanwar, K., and Prasad, A. 2016. "Exploring the Relationship between Employer Branding and Employee Retention." Global Business Review, 17, 186S-206S. https://doi.org/10.1177/0972150916631214

Van Hoye, G., Bas, T., Cromheecke, S., and Lievens, F. 2013. "The Instrumental and Symbolic Dimensions of Organisations' Image as an Employer: A Large-Scale Field Study on Employer Branding in Turkey." Applied Psychology, 62(4), 543-557. https://doi.org/10.1111/j.1464-0597.2012.00495.x

Wahba, M., and Elmanadily, D. 2015. "Employer Branding Impact on Employee Behavior and Attitudes Applied Study on Pharmatecual in Egypt." International Journal of Management and Sustainability, 4(6), 145162. https://doi.org/10.18488/journal.11/2015.4.6/11.6.145.162

Wasti, S. A. 2002. "Affective and continuance commitment to the organization: Test of an integrated model in the Turkish context." International Journal of Intercultural Relations. https://doi.org/10.1016/S01471767(02)00032-9

Wilden, R., Gudergan, S., and Lings, I. 2010. "Employer branding: Strategic implications for staff recruitment." Journal of Marketing Management, 26(1-2), 56-73. https://doi.org/10.1080/02672570903577091

Zinko, R., Furner, Z. Z., Hunt, J., and Dalton, A. 2017. "Establishing a Reputation." Journal of Employment Counseling, 54(2), 87-96. https://doi.org/10.1002/joec.12056 